\title{
Corticosteroid effect upon intestinal and hepatic interleukin profile in a gastroschisis rat mode ${ }^{1}$
}

\author{
Efeito do corticoesteróide sobre o perfil das interleucinas \\ intestinais e hepáticas no modelo de gastrosquise em ratos
}

\author{
Frances Lilian Lanhellas Gonçalves ${ }^{\mathrm{I}}$, Daniel Guimarães Bittencourt ${ }^{\mathrm{II}}$, Lício Augusto Velloso ${ }^{\mathrm{III}}$, Augusto Frederico Schmidt ${ }^{\mathrm{IV}}$, \\ Rodrigo Melo Gallindov', Lourenço Sbragia ${ }^{\mathrm{VI}}$
}

${ }^{\mathrm{I}} \mathrm{PhD}$, Fellow Post-Doctoral degree, Division of Pediatric Surgery, Department of Surgery and Anatomy, School of Medicine of Ribeirao Preto, University of Sao Paulo (FMRP-USP). Ribeirao Preto - SP, Brazil. Data analysis and manuscript writing.

"MD, PhD, Hospital Municipal "Dr. Mario Gatti”. Campinas - SP, Brazil. Surgical procedures, acquisition of data, data analysis and manuscript writing.

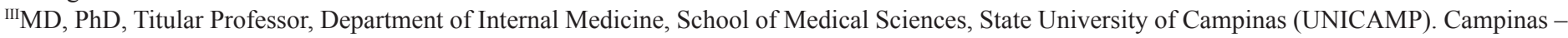
SP, Brazil. Design of study and critical revision.

${ }^{\mathrm{IV}} \mathrm{MD}, \mathrm{PhD}$, Resident, Department of Pediatrics, Cincinnati Children's Hospital Medical Center. Cincinnati - OH, USA. Data analysis.

${ }^{v}$ MD, Fellow Master degree, Division of Pediatric Surgery, Department of Surgery and Anatomy, School of Medicine of Ribeirao Preto, University of Sao Paulo (FMRP-USP). Ribeirao Preto - SP, Brazil. Data analysis.

${ }^{\mathrm{V}} \mathrm{MD}, \mathrm{PhD}$, Associate Professor, Division of Pediatric Surgery, Department of Surgery and Anatomy, School of Medicine of Ribeirao Preto, University of Sao Paulo (FMRP-USP). Ribeirao Preto - SP, Brazil. Mentor, conception and design of study, manuscript writing and critical revision.

\begin{abstract}
PURPOSE: To evaluate the effect of corticosteroids on intestinal and liver interleukin profile in an experimental model of gastroschisis in fetal rats.

METHODS: Sprague-Dawley rats at 19.5 days of gestation had its fetuses operated for the creation of gastroschisis. Two groups of fetuses were studied with and without maternal administration of dexamethasone. Each group was composed of fetuses who underwent gastroschisis $(\mathrm{G})$, control fetuses without manipulation $(\mathrm{C})$ and sham fetuses (S). A dosage of the following interleukins was carried out in fetal intestinal and liver tissues: IL-1, IL-6, IL-10, tumor necrosis factor-alpha (TNF- $\alpha$ ) and interferon-gamma (IFN- $\gamma$ ). The differences between the groups and subgroups were tested by ANOVA with Tukey post-test, with significant values of $p<0.05$.

RESULTS: Dexamethasone led to an increase in intestinal and liver IL-6 $(p<0.05)$ and a decrease in intestinal TNF- $\alpha(p<0.001)$ in fetuses with gastroschisis.

CONCLUSION: Corticosteroids had an effect on the intestinal interleukin profile and a small effect on the liver interleukin profile due to immunological immaturity of the fetus, and also of fetuses with gastroschisis. The steroid action may not be exclusively antiinflammatory, but also pro-inflammatory, varying with time of pregnancy.
\end{abstract}

Key words: Gastroschisis. Inflammation. DexamethasOne. Cytokines. Fetal Development. Rats.

\section{RESUMO}

OBJETIVO: Avaliar a ação do corticosteroide no perfil de interleucinas intestinais e hepáticas no modelo experimental de gastrosquise em fetos de ratos.

MÉTODOS: Ratas Sprague-Dawley com 19,5 dias de gestação tiveram fetos operados para criação de gastrosquise. Dois grupos de fetos foram estudados: com e sem administração materna de dexametasona. Cada grupo foi composto por fetos submetidos a gastrosquise (G), fetos controles sem manipulação (C) e fetos sham (S). Realizou-se a dosagem das seguintes interleucinas no tecido intestinal e hepático fetal: IL-1, IL-6, IL-10, fator de necrose tumoral-alfa (TNF- $\alpha$ ) e interferon-gama (IFN- $\gamma$ ). As diferenças entre os grupos e subgrupos foram testadas pelo teste de ANOVA com pós-teste de Tukey, com valores significativos de $p<0,05$.

RESULTADOS: A dexametasona levou a um aumento da IL-6 intestinal e hepática $(p<0,05)$ e a uma diminuição do TNF- $\alpha$ intestinal $(p<0,001)$ em fetos com gastrosquise.

CONCLUSÃO: O corticosteróide apresentou efeito sobre o perfil de IL intestinal e pouco na hepática, devido a imaturidade imunológica dos fetos e também dos fetos com gastrosquise a ação do esteróide pode não ser exclusivamente anti-inflamatória, mas também pró inflamatória.

Descritores: Gastrosquise. Inflamação. Dexametasona. Citocina. Desenvolvimento Fetal. Ratos. 


\section{Introduction}

Gastroschisis is a congenital defect, which affects five in 10,000 live births ${ }^{1}$, characterized by an opening on the abdominal wall and exposition of bowel loops which are in contact with amniotic fluid (AF) causing a intense inflammation and changes in the intestinal morphology, affecting motility and nutrients absorption $^{2}$.

The prevention or reduction of inflammatory bowel injury has been the subject of recent research in the treatment of gastroschisis. The experimental administration of corticosteroids promotes beneficial effects on fetal intestinal and lung development ${ }^{3,4}$.

In addition to acting on the development, corticosteroids (eg. Dexamethasone) may be potent anti-inflammatory agents; they can also act in the downregulation of proinflammatory and upregulation of anti-inflammatory cytokines when administered prior to cardiac surgery in neonates ${ }^{5}$. These actions can also be extended to fetuses when the corticosteroid is administered to the mother, because it is able to accelerate the maturation of the intestinal mucosal barrier, as well as to increase the activity of some enzymes ${ }^{6}$, acting on the membrane permeability, enzymatic synthesis and mucosa transport.

By inhibiting the synthesis and release of IL-1, corticosteroids also suppress activation of Th cells, thus reducing toxicity and inhibiting the synthesis of various cytokines, such as TNF- $\alpha$ and IFN- $\gamma$. These inflammatory mediators present in gastroschisis, especially the cytokine profile in fetal tissues, have not been well studied ${ }^{7}$.

Thus, to better understand the inflammatory response in gastroschisis and the corticosteroids action in the defect, pro and anti-inflammatory cytokines (IL-1, IL-6, IL-10, TNF- $\alpha$ and IFN- $\gamma$ ) were quantified in the model of experimental gastroschisis in rats fetuses to ascertain which interleukins have changed.

\section{Methods}

An experimental protocol was submitted to and approved by the State University of Campinas (UNICAMP) Animal Research Committee and followed guidelines for the care and use of laboratory animals, internal number 281-1.

\section{Surgery and sample collection}

Sprague-Dawley female rats $(n=10)$, weighing 200 to $250 \mathrm{~g}$, were mated and a vaginal smear to confirm mating was performed on the following day. That day was defined as gestational day 0 for time dating (term=22 days). Pregnant rats were kept in individual cages and acclimated on dark/light cycling conditions. Fetal surgery was performed on 19.5 days of pregnancy. Anesthesia was induced by intramuscular injection of Ketamin $50 \mathrm{mg} / \mathrm{ml}$ (Ketamina ${ }^{\mathrm{R}}$ - Pfizer do Brasil Ltda.) associated with Xylazin $10 \mathrm{mg} / \mathrm{ml}$ (Ropum ${ }^{\mathrm{R}}$ - Bayer do Brasil Ltda.), $0.6 \mathrm{ml}$ for each animal. This anesthetic association (Ketamin $175 \mathrm{mg} /$ $\mathrm{kg}$ and Xylazin $2.5 \mathrm{mg} / \mathrm{kg}$ ) keeps animals in deep anesthesia for 3 hours and promotes 6 to 12 hours painless recovery. The rats were operated under aseptic conditions, on an electrically warmed table regulated at $36{ }^{\circ} \mathrm{C}$. The abdominal ventral region was shaven with an electric razor (Sunbeam ${ }^{\mathrm{R}}$-USA) and cleaned with chlorohexidin soap solution $\left(\right.$ Chlorohex $\left.^{\mathrm{R}}\right)$. The abdominal wall was opened through a median longitudinal incision, then the dams randomly received an intraperitoneal injection of $2 \mathrm{ml}$ of sterile water; or $0.25 \mathrm{mg} / \mathrm{kg}$ dexamethasone (Dx) dissolved in $2 \mathrm{ml}$ of sterile water. The fetuses of each group were subdivided into three sub-groups: gastroschisis (G), control (C) and sham (S). G fetuses were operated according to the Correia-Pinto et al. ${ }^{8}$ technique for partially eviscerating the bowel through a right paramedian opening of the abdominal wall on 19.5 day of gestation. We exposed both legs of the fetus and made the incision with a direct view of the umbilical cord. This position permitted a very safe and controlled incision without damage to the umbilical vasculature. $\mathrm{C}$ fetuses were left undisturbed and $\mathrm{S}$ fetuses were exposed by histerotomy, manipulated but without abdominal wall opening. There were 6 fetuses in each sub-group. The first and last fetuses of each uterine horn were not used. The selection was planned: the second fetus, number 1 to be operated, was G; number 2-C; number 3-S; and so on. Each pregnant rat had at least two fetuses submitted to gastroschisis.

Fetuses were harvested by cesarean section on 21.5 day of gestation and then sacrificed by occipital puncture and a lethal dose of anesthetic. The intestinal tract and the liver were removed and immediately frozen for enzyme-linked immunosorbent assay (ELISA).

\section{Immunoprecipitation and ELISA assay}

Intestinal samples were homogenized in a immunoprecipitation buffer containing 1\% Triton X 100, 100 $\mathrm{mM}$ Tris ( $\mathrm{pH} 7.4$ ), 100mM sodium de pyrophosphate, $100 \mathrm{mM}$ sodium fluoride, $10 \mathrm{mM}$ EDTA, $10 \mathrm{mM}$ sodium vanadate, $2 \mathrm{mM}$ PMSF and $0.1 \mathrm{mg} / \mathrm{mL}$ aprotinin at $4^{\circ} \mathrm{C}$. The homogenate was then centrifuged at $11,000 \mathrm{rpm}$ for 20 minutes. In the supernatant, 
protein concentration was analyzed by the Lowry method and, afterwards, pro-inflammatory IL-1, IL-6, TNF- $\alpha$ e IFN- $\gamma$ and anti-inflammatory IL-10 cytokine levels were obtained on the total protein intestinal tissue extract $(2.0 \mathrm{mg} / \mathrm{ml})$ through ELISA (Pierce Biothecnology, Rockford, IL, USA), accondingly to manufacturer's recommendation.

\section{Statistical analysis}

Statistical analysis was performed using ANOVA test with Tukey's post-test and the statistical significance accepted was $p<0.05$.

\section{Results}

The used technique has been shown to be reliable, and there was neither fetal nor maternal mortality. $G$ fetuses showed remarkable inflammatory intestines, with adhesions between loops and covered by a peel, very similar to that of the human anomaly.

Dx led to an increase of IL-6 and a decrease of TNF- $\alpha$ levels on the intestine of gastroschisis fetuses, and an increase of IL-6 levels on the liver of theses fetuses.

Results of intestinal and hepatic IL1, IL6, IL10, TNF- $\alpha$ and IFN- $\gamma$ with or without additional administration of corticosteroid are condensed in Table 1 and 2, respectively.

TABLE 1 - Results of intestinal IL1b, IL6, IL10, TNF- $\alpha$ and IFN- in fetuses submitted to Gastroschisis, Control and Sham on 19.5 days of gestation.

\begin{tabular}{|c|c|c|c|c|c|c|}
\hline & \multicolumn{3}{|c|}{$\begin{array}{c}\text { Without } \\
\text { corticosteroid }\end{array}$} & \multicolumn{3}{|c|}{$\begin{array}{c}\text { With } \\
\text { corticosteroid }\end{array}$} \\
\hline & $\begin{array}{c}\text { Gastroschisis } \\
n=6\end{array}$ & $\begin{array}{c}\text { Control } \\
n=6\end{array}$ & $\begin{array}{c}\text { Sham } \\
n=6\end{array}$ & $\begin{array}{c}\text { Gastroschisis } \\
n=6\end{array}$ & $\begin{array}{c}\text { Control } \\
n=6\end{array}$ & $\begin{array}{c}\text { Sham } \\
n=6\end{array}$ \\
\hline IL-1b & $47.3( \pm 6.1)^{* \text { ade }}$ & $56.2( \pm 0.3)^{* b^{* * *} \operatorname{cde}}$ & $47.2( \pm 5.5)^{*} \mathrm{de}$ & $42.5( \pm 0.6)$ & $36.5( \pm 6.9)$ & $36.2( \pm 3.2)$ \\
\hline IL-6 & $138.5( \pm 1.1)^{* \mathrm{c}}$ & $153.8( \pm 35.5)$ & $133.8( \pm 20.5)^{* \mathrm{c}}$ & $174( \pm 2.9)^{* d}$ & $129.5( \pm 19)$ & $157( \pm 0.6)$ \\
\hline IL-10 & $27.3( \pm 2.6)^{* \mathrm{ae}}$ & $36.3( \pm 8.4)$ & $31.1( \pm 3.6)$ & $33.3( \pm 0.9)$ & $33.3( \pm 2.6)$ & $35.2( \pm 0.3)$ \\
\hline TNF- $\alpha$ & $0.16( \pm 0.03)^{* * c}$ & $0.19( \pm 0.09)^{*} \mathrm{be}^{* * \mathrm{c}}$ & $0.11( \pm 0.04)^{* \mathrm{c}}$ & $0.02( \pm 0.02)^{* d}$ & $0.12( \pm 0.008)$ & $0.09( \pm 0.03)$ \\
\hline IFN- $\gamma$ & $5.9( \pm 0.9)^{* * \mathrm{~d}}$ & $5.7( \pm 0.5)^{* * \mathrm{~d}}$ & $6.7( \pm 1.5)^{* d}$ & $5.9( \pm 0.31)^{* * d}$ & $9.5( \pm 2.2)^{* *_{\mathrm{e}}}$ & $6.2( \pm 0.8)$ \\
\hline
\end{tabular}

Values $\mathrm{pg} / \mathrm{ml}$ of intestinal tissue homogenate.

$*=\mathrm{p}<0.05 ; * *=\mathrm{p}<0.001$

$\mathbf{a}=$ Compared with Control; $\mathbf{b}=$ Compared with Sham; $\mathbf{c}=$ Compared with Gastroschisis + Corticosteroid; $\mathbf{d}=$ Compared with Control + Corticosteroid; $\mathbf{e}=$ Compared with Sham + Corticosteroid.

TABLE 2 - Results of hepatic IL1b, IL6, IL10, TNF- $\alpha$ and IFN- $\gamma$ in fetuses submitted to Gastroschisis, Control and Sham on 19.5 days of gestation.

\begin{tabular}{|c|c|c|c|c|c|c|}
\hline & \multicolumn{3}{|c|}{$\begin{array}{c}\text { Without } \\
\text { corticosteroid }\end{array}$} & \multicolumn{3}{|c|}{ With corticosteroid } \\
\hline & $\begin{array}{c}\text { Gastroschisis } \\
n=6\end{array}$ & $\begin{array}{c}\text { Control } \\
n=6\end{array}$ & $\begin{array}{c}\text { Sham } \\
n=6\end{array}$ & $\begin{array}{c}\text { Gastroschisis } \\
n=6\end{array}$ & $\begin{array}{c}\text { Control } \\
n=6\end{array}$ & $\begin{array}{c}\text { Sham } \\
n=6\end{array}$ \\
\hline IL-1b & $154.5( \pm 16.2)^{* * \mathrm{~b}}$ & $170( \pm 7.5)^{*_{c}}$ & $207.5( \pm 5.5)^{* *} \mathrm{cde}$ & $159.3( \pm 24.6)$ & $165( \pm 19.6)$ & $157.8( \pm 8.4)$ \\
\hline IL-6 & $463.5( \pm 8.2)^{* \mathrm{c}^{* *} \text { abde }}$ & $616( \pm 76)^{* b}$ & $716( \pm 49.9)^{*_{\mathrm{c}}}$ & $581.3( \pm 48.8)$ & $633( \pm 64.7)$ & $646.5( \pm 33.8)$ \\
\hline IL-10 & $195( \pm 21.4)^{* a e^{* *} \mathrm{bd}}$ & $228.4( \pm 6.6)$ & $245( \pm 7.5)^{*{ }_{c}}$ & $217.5( \pm 8.1)$ & $237.5( \pm 21.4)$ & $229( \pm 4.6)$ \\
\hline TNF- $\alpha$ & $0.10( \pm 0.02)^{* \mathrm{a}^{* *} \mathrm{be}}$ & $0.07( \pm 0.01)^{*^{* * * b c d}}$ & $0.17( \pm 0.009)^{* * \mathrm{cde}}$ & $0.12( \pm 0.01)^{* * k_{e}}$ & $0.12( \pm 0.0004)^{* * \mathrm{e}}$ & $0.04( \pm 0.02)$ \\
\hline IFN- $\gamma$ & $18.9( \pm 9.6)^{* * \mathrm{e}}$ & $24.9( \pm 0.2)^{* \mathrm{bd} \mathrm{d}^{* *} \mathrm{e}}$ & $15.0( \pm 0.8)^{* *_{\mathrm{e}}}$ & $19.6( \pm 2.3)^{* * \mathrm{e}_{\mathrm{e}}}$ & $13( \pm 2.9)^{* * \mathrm{e}}$ & $38.8( \pm 4.5)$ \\
\hline
\end{tabular}

Values $\mathrm{pg} / \mathrm{ml}$ of liver tissue homogenate.

$*=\mathrm{p}<0.05 ; * *=\mathrm{p}<0.001$

$\mathbf{a}=$ Compared with Control; $\mathbf{b}=$ Compared with Sham; $\mathbf{c}=$ Compared with Gastroschisis + Corticosteroid; $\mathbf{d}=$ Compared with Control + Corticosteroid; $\mathbf{e}=$ Compared with Sham + Corticosteroid. 


\section{Discussion}

Survival of newborns with gastroschisis has increased in last decades. However, the intestinal damage is still responsible for high morbidity and, eventually, mortality of these patients. The factors that contribute to morbi-mortality of the disease are direct or indirect consequences of inflammatory process initiated intrauterum, primarily by contact of bowel loops with the intestinal AF.

The bowel inflammation due to contact with the AF, causes functional and morphological changes. The search for a method that prevents or minimizes the intestinal inflammatory lesion is an ongoing effort. Authors developed experimental techniques to avoid contact between the extruded intestine and the AF with favorable results ${ }^{9}$. Other studies include amniocentesis with amnio-dilution and administration of corticosteroids ${ }^{6}$.

Corticosteroids have well known anti-inflammatory actions, and act on the permeability of membranes, enzymatic synthesis and mucosa transport. Its administration at the prenatal period can accelerate the maturation of the intestinal mucosal barrier, as well as to elevate the activity of some enzymes ${ }^{6}$. Its immunosuppressive and anti-inflammatory actions are linked, since both are primarily due to inhibition of specific functions of leukocytes, such as the synthesis and action of cytokines. Corticosteroids inhibit the early steps of inflammation such as edema, fibrin deposition, capillary dilation, leukocyte migration and phagocytic activity. They also suppress the late manifestations, such as proliferation of capillaries and fibroblasts, collagen deposition and scarring.

In pregnant women, the total recommended dose of $\mathrm{Dx}$ is $24 \mathrm{mg}$, corresponding to 0.3 to $0.4 \mathrm{mg} / \mathrm{kg}$. Dx's half-life is $36-72$ hours and Jobe $\&$ Soll ${ }^{4}$ suggested that a single corticosteroid dose of $0.1 \mathrm{mg} / \mathrm{kg}$ would be an effective and less toxic treatment for women in preterm labor.

In this study, we chose the maternal intraperitoneal administration of dexamethasone, assuming that there would be a favorable effect on the fetal intestinal inflammation, as well as on its maturation. We carried out the procedure at the end of gestation, period in which intestinal injury in gastroschisis happens, and coincide with the peak of the fetal intestinal maturation. The Dx dose was defined based on the literature, where positive results have been reported in intestinal and lung maturation, using doses between 0.2 and $0.5 \mathrm{mg} / \mathrm{kg}^{6}$.

We couldn't observe a pattern for the evaluated cytokines in the intestine, i.e., even in the gastroschisis group the proinflammatory and anti-inflammatory cytokine levels were similar to the control group levels. The only cytokines that showed similar levels between the control group and the gastroschisis Dx treated group were IL-6, IL-10 and IFN- $\gamma$.

Similar results were observed in the liver that did not show an expected pattern, although that in this organ, in almost all treated groups, there was no significant difference to the control group without corticosteroid, as if the action of treatment were to match the IL-1, IL-6, IL-10, TNF- $\alpha$ and IFN- $\gamma$ liver levels to near normal values in the fetal body.

An explanation for the fact that it was not possible to identify a unique intestinal cytokine pattern on fetuses with gastroschisis would be a possible extra-intestinal origin of cytokines, such as from the chorio-amniotic system, for example. This hypothesis is based on studies showing that: (1) the cytokines levels in AF increase progressively with the course of pregnancy; (2) apparently in late pregnancy, there is a physiological inflammatory process in the chorio-amniotic tissues, mediated by local production of cytokines; (3) elevated levels of pro-inflammatory cytokines such as TNF- $\alpha$, IL-1, IL- 6 and IL- 8 were observed in the $\mathrm{AF}$ at the end of gestation; (4) the intensity of leukocytic infiltrate in $\mathrm{AF}$ is positively correlated with the levels of these cytokines; (5) the source of cytokines in AF is apparently the amnion and chorion fetal membranes; (6) the impermeability of the placental barrier to cytokines explains the lack of correlation between maternal serum and AF levels under inflammatory conditions; (7) the presence of meconium in the AF has a chemotactic effect on leukocyte and cytokines such as IL-6 and IL-8.

These findings come upon the physiopathology of gastroschisis, since: (1) the greater intestinal damage occurs in the last trimester of pregnancy, coinciding with elevation of cytokines levels in AF; (2) it is believed that an element in AF is responsible for triggering the inflammatory process in gastroschisis; (3) the presence of meconium in the $\mathrm{AF}$ is related to intestinal damage; and (4) the amnio-exchange appears to reduce intestinal inflammation.

Another explanation for this difference in cytokine profile is due to the fetal immune system. Few data are available in the literature on fetal innate immune function, yet, it is sufficient to show that it is essentially different from that observed in term newborns or adults. The phagocytic activity of fetal granulocytes and monocytes is smaller, as well as the cytotoxic $\mathrm{T}$ lymphocytes response that are immature as B lymphocytes. This affects the production of pro-inflammatory cytokines and antibodies ${ }^{10,11}$.

Even the fetal intestinal cells when stimulated produce high levels of nuclear transcription factor kappa B (NF- $\mathrm{B})$ and chemokines when compared with adult cells, but there are gaps in response and in its regulation due to immaturity in immune 
response, contributing significantly to susceptibility to intestinal diseases such as necrotizing enterocolitis ${ }^{12}$.

These results demonstrate that cytokines may not be the most suitable parameter for diagnosing inflammatory intensity that occurs in a tissue or in the fetal body as a whole. A recent study in surgical patients, including gastroschisis, showed that $\mathrm{C}$-reactive protein (CRP), produced by the liver, is an extremely sensitive indicator of inflammation. In addition, corticosteroids treatment did not affect the production of CRP, enabling to quantify them due to the level of inflammation and not for direct intervention in its expression ${ }^{13}$.

The CRP expression can take longer to normalize due to chronic inflammation, which was does not happen with other inflammatory mediators such as IL-1b, IL-6, IL-8, IL-10 and TNF, that doesn't change their levels, and therefore are not useful to monitor a postoperative period, except for that IL-6 increases during 24 hours after a surgical procedure, but returns to its basal levels afterwards ${ }^{13}$.

Moreover, it may not have been possible to identify the interleukin pattern change due to the 48 hours time gap between surgery for gastroschisis and harvest. This monitoring can be accomplished by harvesting at the age of 20.5 days of gestation and finally comparing with term pups.

A better understanding of intrauterine intestinal inflammation could benefit the prognosis and treatment of neonates, not only with gastroschisis, but also with other defects such as myelomeningocele.

\section{Conclusions}

Corticosteroids had an effect on the intestinal interleukin profile and a small effect on the liver interleukin profile due to immunological immaturity of the fetus, and also of fetuses with gastroschisis. The steroid action may not be exclusively antiinflammatory, but also pro-inflammatory, varying with time of pregnancy. Perhaps, assessing in shorter gestational intervals and serially could provide new insights for understanding the steroid action on the interleukin profile in this model.

\section{References}

1. Ghionzoli M, James CP, David AL, Shah D, Tan AW, Iskaros J, Drake DP, Curry JI, Kiely EM, Cross K, Eaton S, De Coppi P, Pierro A. Gastroschisis with intestinal atresia--predictive value of antenatal diagnosis and outcome of postnatal treatment. J Pediatr Surg. 2012;47(2):322-8.

2. Amoury RA, Beatty EC, Wood WG, Holder TM, Ashcraft KW, Sharp RJ, and Murphy JP. Histology of the intestine in human gastroschisis-relationship to intestinal malfunction: dissolution of the "peel" and its ultrastructural characteristics. J Pediatr Surg. 1988; 23:950-6.

3. $\mathrm{Yu}$ J, Gonzalez-Reyes S, Diez-Prdo JA, Tovar JA. Local dexamethsone improves the intestinal lesions of gastroschisis in chick embryos. Pediatr Surg Int. 2004;19(12):780-4.

4. Jobe AH, Soll RF. Choice and dose of corticosteroid for antenatal treatments. Am J Obstet Gynecol. 2004;190(4):878-81.

5. Heying R, Wehage E, Schumacher K, Tassani P, Haas F, Lange R, Hess J, Seghaye MC. Dexamethasone pretreatment provides antiinflammatory and myocardial protection in neonatal arterial switch operation. Ann Thorac Surg. 2012;93(3):869-876. Epub 2012 Jan 29.

6. Buchmiller TL, Shaw KS, Lam ML, Stokes R, Diamond JS, Fonkalsrud EW. Effect of prenatal dexamethasone administration: fetal rabbit intestinal nutrient uptake and disaccharidase development. J Surg Res. 1994;57(2):274-9.

7. Sbragia L, Schmidt AF, Moraes S, Bittencourt DG, Gonçalves FL, Pereira LA, Velloso LA. Inflammatory response in a rat model of gastroschisis is associated with an increase of NF-kappaB. Braz J Med Biol Res. 2010;43(2):160-5.

8. Correia-Pinto J, Tavares ML, Baptista MJ, Estevão-Costa J, Flake AW, and Leite-Moreira AF. A new fetal rat model of gastroschisis: development and early characterization. J Pediatr Surg. 2001;36:2136.

9. Gonçalves FL, da Silva R, Schmidt AF, de Oliveira MG, Sbragia L. Hydrogel protection: a novel approach to reduce bowel inflammation in experimental gastroschisis. Eur J Obstet Gynecol Reprod Biol. 2010;148(1):35-9.

10. Strunk T, Temming P, Gembruch U, Reiss I, Bucsky P, Schultz C. Differential maturation of the innate immune response in human fetuses. Pediatr Res. 2004;56(2):219-26.

11. Chirico G. Development of the Immune System in Neonates. J. Arab Neonatal Forum. 2005;2:5-115.

12. Levy O. Innate immunity of the newborn: basic mechanisms and clinical correlates. Nature Reviews Immunology. 2007;7:379-90.

13. Nguyen-Vermillion A, Juul SE, McPherson RJ, Ledbetter DJ. Time course of C-reactive protein and inflammatory mediators after neonatal surgery. J Pediatr. 2011;159(1):121-6.

\section{Correspondence:}

Lourenço Sbragia

Laboratório de Cirurgia Fetal Experimental "Michael R Harrison"

Departamento de Cirurgia e Anatomia

Faculdade de Medicina de Ribeirão Preto-USP

Avenida Bandeirantes, 3900

14048-900 Ribeirão Preto - SP Brasil

Tel.: (55 16)3602-2593

Fax: $+55-16-3633-0836$

sbragia@fmrp.usp.br

Conflict of interest: none

Financial source: Grant \# 2002/02563-8, 2011/00794-1 and 2011/12587-0 from São Paulo Research Foundation - FAPESP.

${ }^{1}$ Research performed at Laboratory of Experimental Fetal Surgery School of Medicine of Ribeirao Preto, University of Sao Paulo - USP, Ribeirao Preto - SP, Brazil. Mentor: Lourenço Sbragia. 